\title{
Evaluation of Role of Myofibroblasts in Oral Cancer: A Systematic Review
}

\author{
${ }^{1}$ Harjeet K Sekhon, ${ }^{2}$ Keya Sircar, ${ }^{3}$ Gurbani Kaur, ${ }^{4}$ Muneet Marwah
}

\begin{abstract}
Summary of work done by the contributors
All the authors have worked cooperatively on the study. The design of the study was well-versed among all the authors and valuable suggestions were discussed and implemented. All authors coordinated well for the manuscript literature search, preparation, editing, and corrections to be made after review.
\end{abstract}

\section{ABSTRACT}

Aim: To conduct a systematic review on the role of myofibroblasts in progression of oral cancer. The myofibroblast is essential for the integrity of the mammalian body by virtue of its role in wound healing, but it also plays a negative role due to their role in promoting tumor development.

Settings and design: Systematic review.

Materials and methods: Bibliographic searches were conducted in several electronic databases using all publications in PubMed, PubMed central, EMBASE, CancerLit, Google scholar, and Cochrane CCTR between 1990 and June 2015.

Results: The search of all publications from various electronic databases revealed 1,371 citations. The total number of studies considered for systematic review was 43 . The total number of patients included in the studies was 990.

Conclusion: Myofibroblasts are a significant component in stroma of oral cancer cases, though not identified in all cases. This systematic review shows that clinical, pathological, and immunohistochemistry tests have correlated the presence of high myofibroblast count in oral cancer cell stroma.

Keywords: Myofibroblast, Oral cancer, Precancer.

\footnotetext{
${ }^{1}$ Senior Lecturer, ${ }^{2} \mathrm{Head},{ }^{3}$ Ex-post Graduate Student, ${ }^{4}$ Postgraduate

${ }^{1}$ Department of Oral Pathology and Microbiology, D.J. College of Dental Sciences \& Research, Modinagar, Uttar Pradesh, India

${ }^{2}$ Department of Oral Pathology and Microbiology, Faculty of Dentistry, Jamia Millia Islamia, New Delhi, India

${ }^{3}$ Department of Periodontology, Dr. D.Y. Patil Dental College and Hospital, Dr. D.Y. Patil Vidyapeeth, Pune, Maharashtra, India

${ }^{4}$ Department of Prosthodontics, Government Dental College Thiruvananthapuram, Kerala, India

Corresponding Author: Harjeet K Sekhon, Senior Lecturer Department of Oral Pathology and Microbiology, D.J. College of Dental Sciences \& Research, Modinagar, Uttar Pradesh India Phone: +919716146746, e-mail: bblsekhon86@gmail.com
}

Key Messages: Myofibroblasts play a significant role in oral cancer invasion and progression. Various studies have demonstrated their association with oral cancer. This review tends to highlight their role in the pathogenesis of oral cancer over the decade.

How to cite this article: Sekhon HK, Sircar K, Kaur G, Marwah M. Evaluation of Role of Myofibroblasts in Oral Cancer: A Systematic Review. Int J Clin Pediatr Dent 2016;9(3):233-239.

Source of support: Nil

Conflict of interest: None

\section{INTRODUCTION}

The myofibroblasts are a type of fibroblasts, which constitute a family of paracrine cells that play an important role in the regulation of fundamental processes, such as cell motility, proliferation, differentiation, apoptosis, morphogenesis, tissue repair, inflammation, and the immune response. ${ }^{1-3}$ It has been identified as the cell which produces stress fibers, have alpha-smooth muscle expression and even help in the production of tension, collagen fibrils, and growth factors. ${ }^{4}$ Their presence has been described practically in all fibrotic situations characterized by tissue retraction and remodeling. ${ }^{5}$ In many organs like liver, lung, and kidney, they are primarily involved in fibrosis. In the wound tissue, it is implicated in wound strengthening by extracellular collagen fiber deposition and then wound contraction by intracellular contraction and concomitant alignment of the collagen fibers by integrin-mediated pulling onto the collagen bundles. ${ }^{6}$ Myofibroblast may be considered as a foe or friend due to their beneficial role in normal healing granulation tissue and its damaging effects when it occurs in hypertrophic scars, scleroderma, dupuytrene disease, fibromatosis, fibrotic response to implants, lung fibrosis, heart fibrosis, kidney fibrosis, atheromatous plaque evolution, and chronic asthma.

The term "oral cancer" includes all the malignancies arising from lips, oral cavity, oropharynx, nasopharynx, hypopharynx, and other ill-defined sites within lip, oral cavity, and pharynx. ${ }^{7}$ In accordance to the study of diverse pathologic conditions in which the myofibroblast has been described, three fundamental processes were identified in 1980: Diverse responses to injury and repair phenomena, quasi-neoplastic proliferative conditions, the 
stromal response to certain forms of neoplasia. ${ }^{8}$ Many invasive and the metastatic carcinomas, especially those characterized by their hard consistency, retraction, and fixation to adjacent tissues, elicit a desmoplastic stromal reaction. The reaction that occurs in these carcinomas is brought about by stromal myofibroblasts. ${ }^{9,10}$

It was originally believed that the myofibroblastic stromal reaction represented a host response to cancer possibly to contain the invasive neoplasm. ${ }^{11}$ However, few authors have suggested that in invasive sarcomas, the stromal myofibroblast secretes stromal-degrading enzymes, which would favor cancer invasion. ${ }^{12}$ Myofibroblasts also produce a variety of factors that are involved in the pathogenesis of oral submucous fibrosis (OSMF). ${ }^{13}$ Myofibroblasts interact with epithelial cells and other connective tissue cells and may thus control phenomenon as tumor invasion and angiogenesis. ${ }^{14}$ Some studies have suggested secretion of enzymes that degrade the extracellular matrix, thereby facilitating tumor invasion by the myofibroblasts. ${ }^{9}$ The aim of this study was to systematically review the literature on the role of myofibroblasts in oral cancer development and progression.

\section{MATERIALS AND METHODS}

The bibliographic searches were conducted in several electronic databases using all publications in PubMed, PubMed central, EMBASE, CancerLit, Google scholar, and Cochrane CCTR between 1990 and June 2015.

Criteria for considering studies:

Studies were considered eligible for study when they fulfilled the following criteria:

- Randomized controlled trials

- Experimental studies conducted on human species

- Observational studies with a comparison and control group.

- Full-text review articles

- Case reports Exclusion criteria were as follows:

- Duplicate studies

- Unpublished data

- Studies involving animal species.

The primary outcome considered in this study was to evaluate the role of myofibroblasts in progression of oral cancer and analyze their prevalence in oral cancer cases. Other outcome included was prevalence in potentially premalignant oral lesions.

\section{SEARCH STRATEGY}

Articles with relevance to search were identified from the abovementioned electronic databases. The search strategy used the terms from three categories: Oral anatomical parts, cancer, myofibroblasts, and was supplemented with search of text (Table 1).

In addition, hand searching was performed for fulltext articles from the following journals: British Dental Journal, J Pathol, J Oral Pathol Med, Oral Oncology, and Histochem Cell Biol. For each included study, the following data were recorded: Year of publication, country of origin, details of participants, including demographic characteristic and details of study design according to Section 6.7.1 of Cochrane Reviewer's Handbook. ${ }^{15}$

\section{RESULTS}

The search of all publications from various electronic databases revealed 1,371 citations (Flow Chart 1 ). ${ }^{16}$ Searches of EMBASE, Google scholar, CancerLit, Cochrane CCTR, and bibliographies of review articles did not reveal any further relevant studies that had not been identified by PubMed search. Similarly, hand searching in the identified journals did not identify any other studies.

However, after implementing the terms of the search-strategy inclusion criteria, the studies that could be considered for systematic review reduced to 43 (Table 2). 1,2,6,9,10,11-14,17-48

Table 1: Keywords used in the literature search

\begin{tabular}{lll}
\hline Oral & Cancer & Myofibroblast \\
Mouth & Mouth neoplasm & \\
Lip & Precancerous condition & \\
Gingiva & Tumor \\
Tongue & Carcinoma \\
Oropharynx & Malignant \\
& Dysplasia \\
\hline
\end{tabular}

Flow Chart 1: Study design
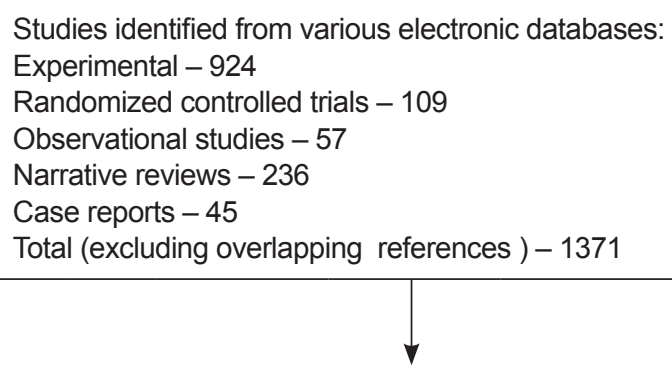

Records screened for relevance, full text articles assessed for eligibility

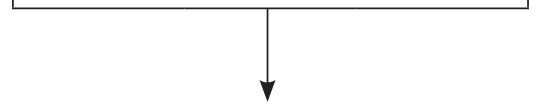

Studies included in the systematic review - 43 
Table 2: Characteristics of studies included in investigating prevalence of myofibroblasts in oral cancer

\begin{tabular}{|c|c|c|c|}
\hline References & $\begin{array}{l}\text { Year of } \\
\text { publication }\end{array}$ & $\begin{array}{l}\text { Journal of } \\
\text { publication }\end{array}$ & Details of the study \\
\hline Zidar et al ${ }^{17}$ & 2002 & Oncology & $\begin{array}{l}\text { Sample }-n_{1}=42 \text { (resected larynx) } n_{2}=40 \text { (laryngeal biopsies } \\
\text { of epithelial hyperplastic lesions and squamous carcinoma- } \\
\text { myofibroblast found exclusively in squamous carcinoma) }\end{array}$ \\
\hline Barth et $a^{18}$ & 2004 & Virchows Arch & $\begin{array}{l}\text { Sample }-\mathrm{n}=39 \text { (OSCC and tumor-free oral mucosa) } \\
31 \text { carcinomas showed increased stromal a SMA positive } \\
\text { myofibroblast }\end{array}$ \\
\hline Lewis et al ${ }^{19}$ & 2004 & Br J Cancer & $\begin{array}{l}\text { Sample }-\mathrm{n}=25 \text { ( } 15 \text { OSCC and } 10 \text { fibro epithelial hyperplasia) } \\
\text { Myofibroblastic differentiation is commonly seen in the stroma of } \\
\text { OSCC (11), particularly at the invasive front of the tumor, no a SMA } \\
\text { positive myofibroblast in the connective tissue of fibroepithelial } \\
\text { hyperplasia }\end{array}$ \\
\hline Vered et $\mathrm{al}^{20}$ & 2005 & Oral Oncol & $\begin{array}{l}\text { Sample }-n=53 \text {, high frequency of stromal myofibroblast in known } \\
\text { aggressive odontogenic lesion, such as odontogenic keratocyst } \\
\text { parakeratinized type and solid ameloblastoma implies that } \\
\text { myofibroblast can contribute to the biological behavior of these } \\
\text { odontogenic lesions }\end{array}$ \\
\hline Kellermann et $\mathrm{al}^{21}$ & 2007 & Histopathology & $\begin{array}{l}\text { Sample }-n=117, \text { myofibroblast in the stroma of the oral carcinoma } \\
\text { are associated with poor prognosis }\end{array}$ \\
\hline Kellermann et $\mathrm{al}^{22}$ & 2008 & Oral Oncol & $\begin{array}{l}60 \% \text { of the OSCC contain myofibroblast in the stroma of the tumor } \\
\text { During tumor invasion OSCC-derived TGF- } \beta 1 \text { promote fibroblast } \\
\text { myofibroblast transdifferentiation and tumor cell proliferation can } \\
\text { be induced by factors released from myofibroblast favoring tumor } \\
\text { growth }\end{array}$ \\
\hline Verad et $\mathrm{al}^{23}$ & 2009 & Cancer Microenviron & $\begin{array}{l}\text { Sample }-n=19 \text { (pair matched-oral tongue SCC and metastatic } \\
\text { tumor to regional lymph node), expression of cancer-associated } \\
\text { fibroblast is common to both primary and metastatic SCC }\end{array}$ \\
\hline Franz et $\mathrm{al}^{24}$ & 2009 & Histochem Cell Biol & $\begin{array}{l}\text { Sample }-n=152, \text { Snail-positive cell in the stroma of OSCC } \\
\text { invasive front without statistically significant correlation, histological } \\
\text { grade, or nodal metastasis. }\end{array}$ \\
\hline Kawashiri et al ${ }^{25}$ & 2009 & Head Neck & $\begin{array}{l}\text { Sample }-n=84 \text {, high level of stromal collagen fibers in invasive } \\
\text { tumors, myofibroblast appearance increased with increasing tumor } \\
\text { invasiveness with frequent lymph node metastasis }\end{array}$ \\
\hline $\begin{array}{l}\text { Etemad-Moghadam } \\
\text { et } \mathrm{al}^{26}\end{array}$ & 2009 & J Oral Pathol Med & $\begin{array}{l}\text { Sample }-n=70 \text {, presence of myofibroblast in the stroma of OSCC } \\
\text { but not in dysplasia and normal mucosa }\end{array}$ \\
\hline Franz et $\mathrm{al}^{27}$ & 2010 & J Oral Pathol Med & $\begin{array}{l}\text { Sample }-n=5 \text {, mediated by myofibroblast OSCC development is } \\
\text { associated with a stromal upregulation of laminin isoform possibly } \\
\text { contributing to a migration promoting microenvironment }\end{array}$ \\
\hline Seifi et $\mathrm{al}^{28}$ & 2010 & Asian Pac J Cancer Prev & $\begin{array}{l}\text { Sample }-n=54 \text {, increase in the number of myofibroblast and } \\
\text { change in the distribution pattern occur during carcinogenesis } \\
\text { signifying their role in tumor invasion characteristics }\end{array}$ \\
\hline Sobral et al ${ }^{29}$ & 2011 & Oral Oncol & $\begin{array}{l}\text { Sample }-n=30, \text { myofibroblast in the stroma of OSCC may } \\
\text { influence proliferation and invasion }\end{array}$ \\
\hline $\begin{array}{l}\text { Salgueiredo-Giudice } \\
\text { et } \mathrm{al}^{30}\end{array}$ & 2011 & $\begin{array}{l}\text { Oral Surg } \\
\text { Oral Med } \\
\text { Oral Pathol } \\
\text { Oral Radiol Endod }\end{array}$ & $\begin{array}{l}\text { Sample }-n=3 \text {, demonstration of IHC profile of oral inflammatory } \\
\text { myofibroblastic tumor along with morphological analysis reveals } \\
\text { positive for calponin, vimentin, } \alpha \text {-SMA, fibronectin }\end{array}$ \\
\hline Angadi et al $^{13}$ & 2011 & J Oral Pathol Med & $\begin{array}{l}\text { Sample }-n=85, \text { statistically significant increase in the } \\
\text { myofibroblast between early and advance stages was observed }\end{array}$ \\
\hline Sridhara et al ${ }^{31}$ & 2013 & J Oral Maxillofac Pathol & $\begin{array}{l}\text { Sample }-n=10, \alpha \text {-SMA cases were more in the metastatic group } \\
\text { than in the nonmetastatic tumor }\end{array}$ \\
\hline Lúcio et al ${ }^{32}$ & 2013 & Braz J Otorhinolaryngol & Myofibroblasts are important components of the stroma for SCC \\
\hline Angadi et $\mathrm{al}^{33}$ & 2014 & Ada Odontol Scand & $\begin{array}{l}\text { Sample }-n=65,(50-O S C C \text { and histologically normal mucosa } \\
\text { adjacent to OSCC, } 15 \text {-control) significant co-relation was } \\
\text { established for the presence of myofibroblast in the stroma of OSCC } \\
\text { and HNMAOSCC. Myofibroblasts are early stromal change in the } \\
\text { HNMAOSCC that highlights the possible role of myofibroblast as } \\
\text { likely mediator for field cancerization }\end{array}$ \\
\hline Routray et al ${ }^{34}$ & 2014 & Oral Dis & $\begin{array}{l}\text { Myofibroblast can arise locally from endothelial mesenchymal } \\
\text { transformation at the invasive edge of the cancer leading to } \\
\text { development of high-grade malignancies and poor prognosis }\end{array}$ \\
\hline
\end{tabular}




\begin{tabular}{|c|c|c|c|}
\hline References & $\begin{array}{l}\text { Year of } \\
\text { publication }\end{array}$ & $\begin{array}{l}\text { Journal of } \\
\text { publication }\end{array}$ & Details of the study \\
\hline Pinisetti et $\mathrm{al}^{35}$ & 2014 & J Oral Maxillofac Pathol & $\begin{array}{l}\text { Myofibroblast in focal epithelial dysplasia and SCC revealed a } \\
\text { higher number of myofibroblast in OSCC }\end{array}$ \\
\hline Rao et $\mathrm{al}^{36}$ & 2014 & J Clin Diagn Res & $\begin{array}{l}\text { Sample } n=62 \text { ( } 41 \text { - OSMF, } 10-\text { OSMF with dysplasia and } 11-\text { OSCC). } \\
\text { Presence of myofibroblasts was significantly higher in OSCC }\end{array}$ \\
\hline Luksic et al ${ }^{49}$ & 2015 & Int J Oral Maxillofac Surg & $\begin{array}{l}\text { Sample } n=152 \text {, myofibroblast proliferation was suggested to } \\
\text { facilitate tumor invasion and distant metastasis }\end{array}$ \\
\hline Guan et $a^{50}$ & 2015 & Histopathology & $\begin{array}{l}\text { Immunohistochemically, significant difference was observed in } \\
\text { a-SMA expression in between normal controls and adenoid cystic } \\
\text { carcinoma. This study demonstrated presence of myofibroblasts in } \\
\text { adenoid cystic carcinoma. }\end{array}$ \\
\hline Jensen et $a^{51}$ & 2015 & J Oral Pathol Med & $\begin{array}{l}\text { In this study, budding tumor cells had decreased expression of } \\
\text { E-cadherin. Thus, it is suggested that budding tumor cells in OSCC } \\
\text { is not dependent upon either myofibroblast or complete epithelial- } \\
\text { mesenchymal transition. }\end{array}$ \\
\hline
\end{tabular}

OSCC: Oral squamous cell carcinoma; HNMAOSCC: Histologically normal mucosa adjacent to oral squamous cell carcinoma; IHC: Immunohistochemistry; SMA: Smooth muscle actin; OSMF: Oral submucous fibrosis

\section{DISCUSSION}

In neoplasia, proliferation of myofibroblasts was as a host stromal response to invasive carcinomas characterized by desmoplasia. ${ }^{2}$ The persistence of myofibroblast in a fibrotic lesion leads to scarring along with the functional impairment of the affected organ. The sustained myofibroblast activation stimulates the dysfunction repair mechanisms, leading to accumulation of fibrotic extracellular matrix, i.e., rich in collagens that bind to form fibrous bundles that are resistant to degradation. The fibrotic extracellular matrix disrupts cell polarity and stimulates cell proliferation, which creates an environment for the cancer formation and progression. Myofibroblast-induced inflammation and angiogenesis facilitate tumor growth and progression. ${ }^{37}$

Many epithelial tumors are characterized by the local accumulation of connective tissue cells and extracellular material; this phenomenon is known as the stromal reaction. The interaction of myofibroblast with epithelial cells and other connective tissue cells may control such phenomenon as tumor invasion and angiogenesis. ${ }^{14}$

In the recent history some studies have suggested secretion of enzymes that degrade the extracellular matrix, thereby facilitating tumor invasion by the myofibroblasts. ${ }^{9}$

Transdifferentiation of the fibroblasts to the myofibroblasts is a crucial and early event in tumorigenesis, which is mediated by the growth factors and cytokines, such as transforming growth factor-beta (TGF-beta) expressed by the tumor cells. ${ }^{38}$

Squamous carcinoma cells may induce a myofibroblast phenotype in primary fibroblasts through the secretion of TGF-beta. ${ }^{39}$ Transforming growth factorbeta causes cancer progression through paracrine and autocrine effects. Paracrine effects of TGF-beta include the stimulation of angiogenesis, escape from immunosurveillance and recruitment of myofibroblasts, while the autocrine effects of TGF-beta in cancer cells with a functional TGF-beta receptor complex may be caused by a convergence between TGF-beta signaling and betacatenin or activating Ras mutations. ${ }^{40}$

The myofibroblasts along with immune cells support blood vessel formation, breakdown of basement membrane barriers, and facilitate tumor invasion and metastasis. They significantly upregulate the secretion of hepatocyte growth factor, which promotes invasion of squamous cell carcinoma. ${ }^{39}$

Various experimental and clinical observations indicate the production of pro-invasive signals by the myofibroblasts which are implicated in cancer pain. N-Cadherin, expressed by myofibroblasts, promotes matrix invasion, perineural invasion, muscular invasion, and transendothelial migration. ${ }^{40}$

Epithelial cell proliferation is mediated by growth factors and inflammatory mediators secreted by myofibroblasts. The role of myofibroblasts in promoting invasion has been shown in numerous aggressive and malignant neoplasms. Zidar et $\mathrm{al}^{17}$ demonstrated that myofibroblasts were positive for vimentin and smooth muscle actin. This indicated that invasion beyond the basement membrane is necessary for the occurrence of the myofibroblastic stromal reaction. Two patterns of stromal reaction were observed in squamous carcinomas:

1. Characterized by a marked proliferation of myofibroblasts and desmoplasia, with scarce lymphocytic infiltration. This pattern was associated with well- or moderately differentiated squamous carcinoma.

2. Characterized by few myofibroblasts, weak desmoplasia, and dense lymphocytic infiltration. This pattern 
was associated with moderately or poorly differentiated squamous carcinoma.

The degree of myofibroblast proliferation was inversely related to the density of lymphocytic infiltration. ${ }^{17}$ In invasive oral squamous cell carcinoma, an increase in smooth muscle actin-positive myofibroblasts has been observed. Etemad-Moghadam et $\mathrm{al}^{26}$ conducted a study that demonstrated an increased number of myofibroblasts in oral squamous cell carcinomas compared to normal and dysplastic epithelium.

Kellermann et $\mathrm{al}^{21}$ studied the prognostic significance of myofibroblasts in squamous cell carcinoma of tongue, preleukoplakia with histological dysplasia, and in normal tongue mucosa. No myofibroblasts were detected in the stroma of the normal mucosa or epithelial dysplasia which is in agreement with the results obtained by Etemad-Moghadam et al. ${ }^{26}$ Lewis et al ${ }^{19}$ demonstrated the presence of myofibroblast in the vicinity of invasive squamous cell carcinoma but not in the mucosal polyps. Kellermann et $\mathrm{al}^{21}$ and Vered et $\mathrm{al}^{23}$ have described the presence of the myofibroblast in the stroma of most human oral squamous cell carcinoma. Two dominant patterns discovered were:

1. Spindle

2. Network

In the "network" pattern, myofibroblasts are exceptionally abundant and occupy almost the entire tumor stroma.

The "spindle" pattern is characterized by stromal myofibroblast that have spindle-shaped morphology and are located at the periphery of carcinomas as one to three concentric layers, a pattern that can also be found adjacent to a few or many tumor islands/nests. ${ }^{21,23}$

The presence of myofibroblasts in squamous cell carcinoma is considered to be inductive phenomena. The epithelial-stromal interactions, different growth factors released by malignant epithelial cells induce, have been considered as source for the myofibroblasts. ${ }^{26}$

In a study to assess the frequency of stromal myofibroblast in the different odontogenic cysts and tumors, Vered et $\mathrm{al}^{20}$ found that the number of $\alpha$ smooth muscle-actin positive stromal cells or myofibroblasts was significantly higher in odontogenic keratocysts as compared to dentigerous cysts. The myofibroblast counts in the parakeratinized odontogenic cyst and solid ameloblastoma were not significantly different from that in the squamous cell carcinoma. The number of myofibroblasts in the unicystic ameloblastoma and the ameloblastic fibroma was comparatively lower than that in the more aggressive odontogenic tumors and cysts. Thus, it was suggested that the myofibroblast has the potential to facilitate progression of epithelial lesions, and this can contribute to the biological behavior of these odontogenic lesions.

Based on semi-quantitative histological studies, myofibroblasts have been associated with tumor progression in various ways. Kellermann found an abundance of myofibroblast to be associated with the $\mathrm{N}$-stage but not with tumor size (T stage). ${ }^{21,41-48}$ Most studies show increased quantities of myofibroblast to be associated with poor prognosis.

\section{CONCLUSION}

Myofibroblasts are significant components in the stroma of oral cancer lesions, though they may not be identified in all cases. A review of the literature indicates that myofibroblasts play an important role in facilitating invasion by oral squamous cell carcinoma by expression of growth factors, cytokines, extracellular components, ${ }^{21}$ and various proteolytic enzymes. This systematic review shows that clinical, pathological, and immunohistochemistry tests have correlated the presence of high myofibroblast count in oral cancer cell stroma. Most of these observations have been made in the last few years from 1990 to 2015 . Thus there is a need for further research to understand the molecular mechanisms by which myofibroblasts impact the biological behavior of oral squamous cell carcinoma.

\section{REFERENCES}

1. Eyden B. The myofibroblast in health and disease. Rev Esp Patol 2008;41(1):3-10.

2. Derek R, Paraic AK, Mina JB. Fibrosis and cancer: myofibroblast come also from epithelial cells via EMT? J Cell Biochem 2007 Jul 1;101(4):830-839.

3. Powell WD, Miffin RC, Valentich JD, Crowse SE, Saada JI, West AB. Myofibroblasts: I. Paracrine cells important in health and disease. Am J Physiol 1999 Jul;277(1 Pt 1):C1-C9.

4. Powell DW. Myofibroblasts: paracrine cells important in health and disease. Trans Am Clin Climatol Assoc 2000;111: 271-292.

5. Desmouliere A, Darby IA, Gabbiani G. Normal and pathological soft tissue remodeling: role of the myofibroblast, with special emphasis on liver and kidney fibrosis. Lab Invest 2003 Dec;83(12):1689-1707.

6. Gabbiani G, Ryen GB, Majno G. Presence of modified fibroblast in granulation tissue and their possible role in wound contraction. Experientia 1971 May;27(5):549-550.

7. Kujan O, Glenny MA, Duxbury J, Thakker N, Sloan P. Evaluation of screening strategies for improving oral cancer mortality: a Cochrane systematic review. J Dent Educ 2005 Feb;69(2):255-265.

8. Seemayer TA, Lagacé R, Schurch W, Thelmo WL. The myofibroblast: biologic, pathologic and theoretical considerations. Pathol Annu 1980;15(Pt 1):443-470.

9. Walter S, Gabbiani G, Thomas AS. The myofibroblast a quarter century after its discovery. Am J Surg Pathol 1998 Feb;22(2):141-147. 
10. Lagacé R, Schürch W, Seemayer TA. Myofibroblasts in the soft tissue sarcomas. Virchows Arch A Pathol Anat Histol 1980;389(1):1-11.

11. Seemayer TA, Lagacé $R$, Schurch $W$. On the pathogenesis of sclerosis and nodularity in nodular sclerosing Hodgkin's disease. Virchows Arch A Pathol Anat Histol 1980;385(3): 283-291.

12. Seemayer TA, LagacéR, Schurch $W$, Tremblay G. Myofibroblasts in the stroma of invasive and the metastatic carcinoma: a possible host response to neoplasia. Am J Surg Pathol 1979 Dec;3(6):525-533.

13. Angadi PV, Kale AD, Hallikerimath S. Evaluation of myofibroblasts in oral submucous fibrosis: correlation with disease severity. J Oral Pathol Med 2011 Mar;40(3):208-213.

14. Gabbiani G. The evolution of the myofibroblast concept: a key cell for wound healing and fibrotic diseases. G Gerontol 2004;52:280-282.

15. Clarke M, Oxman AD. Cochrane reviewers' handbook 4.1.6. The Cochrane library. Oxford: Update Software; 2003 (updated quarterly).

16. Moher D, Liberati A, Tetzlaft J, Altman DG, PRISMA Group. Preferred reporting items for systematic reviews and metaanalysis: the PRISMA statement. Ann Intern Med 2009 Aug 18;151(4):264-269.

17. Zidar N, Gale N, Kambic V, Fischinger J. Proliferation of myofibroblasts in the stroma of epithelial hyperplastic lesions and squamous carcinoma of the larynx. Oncology 2002;62(4):381-385.

18. Barth PJ, Schenck zu Schweinsberg T, Ramaswamy A, Moll R. CD34+ fibrocytes, alpha-smooth muscle antigen-positive myofibroblasts, and CD117 expression in the stroma of invasive squamous cell carcinomas of the oral cavity, pharynx, and larynx. Virchows Arch 2004 Mar;444(3):231-234.

19. Lewis MP, Lygoe KA, Nystrom ML, Anderson WP, Speight PM, Marshall JF, Thomas GJ. Tumor-derived TGF-beta1 modulates myofibroblast differentiation and promotes HGF/ SF-dependent invasion of squamous carcinoma cells. Br J Cancer 2004 Feb 23;90(4):822-832.

20. Vered M, Shohat I, Buchner A, Dayan D. Myofibroblasts in the stroma of odontogenic cysts and tumors can contribute to variations in the biologic behavior of lesions. Oral Oncol 2005 Nov 4;41(10):1028-1033.

21. Kellermann MG, Sobral LM, Da Silva SD, Zecchin KG, Graner E, Lopes MA. Myofibroblasts in the stroma of oral squamous cell carcinoma is associated with poor prognosis. Histopathology 2007 Dec;51(6):849-853.

22. Kellermann MG, Sobral LM, Da Silva SD, Zecchin KG, Graner E, Lopes MA, Kowalski LP, Coletta RD. Mutual paracrine effects of oral squamous cell carcinoma cells and normal oral fibroblasts: induction of fibroblast to myofibroblast transdifferentiation and modulation of tumor cell proliferation. Oral Oncol 2008 May;44(5):509-517.

23. Vered M, Allon I, Buchner A, Dayan D. Stromal myofibroblasts accompany modification in the epithelial phenotype of tongue dysplastic and malignant lesions. Cancer Microenviron 2009 Dec;2(1):49-57.

24. Franz M, Spiegel K, Umbreit C, Richter P, Codina-Canet C, Berndt A, Altendorf-Hofmann A, Koscielny S, Hyckel P, Kosmehl H, et al. Expression of Snail is associated with myofibroblast phenotype development in oral squamous cell carcinoma. Histochem Cell Biol 2009 May;131(5):651-660.
25. KawashiriS, Tanaka A, Noguchi N,Hase T, Nakaya H, Ohara T. Significance of stromal desmoplasia and myofibroblast appearance at the invasive front in squamous cell carcinoma of the oral cavity. Head Neck 2009 Oct;31(10):1346-1353.

26. Etemad-Moghadam S, Khalili M, Tirgary F, Alaeddini M. Evaluation of myofibroblasts in oral epithelial dysplasia and squamous cell carcinoma. J Oral Pathol Med 2009 Sep;38(8):639-643.

27. Franz M, Wolheim A, Richter P, UmbreitC, Dahse R, DriemelO, Hyckel P, Virtanen I, Kosmehl H, Berndt A. Stromal laminin chain distribution in normal, hyperplastic and malignant oral mucosa: relation to myofibroblast occurrence and vessel formation. J Oral Pathol Med 2010 Apr;39(4):290-298.

28. Seifi S, Shafahi S, Shafigh E, Sahabi SM, Ghasemi H. Evaluation for the presence of -SMA positive myofibroblasts in oral squamous cell carcinomas, and oral epithelial dysplasia and hyperkeratosis. Asian Pac J Cancer Prev 2010;11(2): 359-364.

29. Sobral LM, Bufalino A, Lopes MA, Graner E, Salo T, Coletta RD. Myofibroblasts in the stroma of oral cancer promote tumorigenesis via secretion of activin A. Oral Oncol 2011 Sep;47(9):840-846.

30. Salgueiredo-Giudice F, Fornias-Sperandio F, Martins-Pereira E, da Costa dal Vechio AM, deSousaSC, dos Santos-Pinto-Junior D. The immunohistochemical profile of oral inflammatory myofibroblastic tumors. Oral Surg Oral Med Oral Pathol Oral Radiol Endod 2011 Jun;111(6):749-756.

31. Sridhara SU, Choudaha N, Kasetty S, Joshi PS, Kallianpur S, Tijare M. Stromal myofibroblasts in nonmetastatic and metastatic oral squamous cell carcinoma: an immunohistochemical study. J Oral Maxillofac Pathol 2013 May-Aug;17(2): 190-194.

32. Lúcio PS, Cavalcanti AL, Alves PM, Godoy GP, Nonaka CF. Myofibroblasts and their relationship with oral squamous cell carcinoma. Braz J Otorhinolaryngol 2013 Jan-Feb;79(1):112-118.

33. Angadi PV, Patil PV, Kale AD, Hallikerimath S, Babji D. Myofibroblast presence in apparently normal mucosa adjacent to oral squamous cell carcinoma associated with chronic tobacco/areca nut use: evidence for field cancerization. Acta Odontol Scand 2014 Oct;72(7):502-508.

34. Routray S, Sunkavali A, Bari KA. Carcinoma-associated fibroblasts, its implication in head and neck squamous cell carcinoma: a mini review. Oral Dis 2014 Apr;20(3):246-253.

35. Pinisetti S, Manyam R, Suresh B, Aparna V. Myofibroblasts in oral lesions: a review. J Oral Maxillofac Pathol 2014 JanApr;18(1):52-57.

36. Rao KB, Malathi N, Narashiman S, Rajan ST. Evaluation of myofibroblasts by expression of alpha smooth muscle actin: a marker in fibrosis, dysplasia and carcinoma. J Clin Diagn Res 2014 Apr;8(4):ZC14-ZC17.

37. Radisky DC, Kenny PA, Bissell JB. Fibrosis and cancer: myofibroblast come also from epithelial cells via EMT? J Cell Biochem 2007 Jul 1;101(4):830-839.

38. Phan SH. Biology of fibroblasts and myofibroblast. Proc Am Thorac Soc 2008 Apr 15;5(3):334-337.

39. ThodeC, Jorgensen TG, Dabelsteen E,Mackenzie I, DabelsteenS. Significance of myofibroblasts in oral squamous cell carcinoma. J Oral Pathol Med 2011 Mar;40(3):201-207.

40. Wever OD, Mareel M. Role of tissue stroma in cancer cell invasion. J Pathol 2003 Jul;200(4):429-443.

41. Orimo A, Tomioka Y, Shimizu Y. Cancer associated myofibroblasts possess various growth factors to promote 
endometrial tumor progression. Clin Cancer Res 2001 Oct;7(10):3097-3105.

42. Hay ED. Organization and fine structure of epithelium and mesenchyme in the developing chick embryo. In: Fleischmajer R, Billingham RE, editors. Epithelial-mesenchymal interactions. Baltimore (MD): Williams and Wilkins; 1968. p. 31-55.

43. Hinz B. The myofibroblast, one function, multiple origins. Am J Pathol 2007 Jun;17(6):1807-1816.

44. Iwasaki H, Isayama T, IChiki T, Kikuchi M. Intermediate filaments of myofibroblasts. Immunochemical and immunocytochemical analyses. Pathol Res Pract 1987 Apr;182(2): 248-254.

45. Eyden B. Electron microscopy in the study of myofibroblastic lesions. Semin Diagn Pathol 2003 Feb;20(1):13-24.

46. Eyden BP. Brief review of the fibronexus and its significance for myofibroblastic differentiation and tumor diagnosis. Ultrastruct Pathol 1993 Nov-Dec;17(6):611-622.
47. Kohnen G, Kertschanska S, Demir R, Kaufmann P. Placental villous stroma as a model system for myofibroblast differentiation. Histochem Cell Biol 1996 Jun;105(6):415-429.

48. Gabbiani G. The myofibroblast in wound healing and fibrocontractive diseases. J Pathol 2003 Jul;200(4):500-503.

49. Luksic I, Suton P, ManojlovicS, Virag M, Petrovecki M, Macan D. Significance of myofibroblast appearance in squamous cell carcinoma of the oral cavity on the occurrence of occult regional metastases, distant metastases, and survival. Int J Oral Maxillofac Surg 2015 Sep;44(9):1075-1080.

50. Guan H, Tan J, Zhang F, Gao L, Bai L, Qi D, Dong H, Zhu L, Li X, Liu T. Myofibroblasts from salivary gland adenoid cystic carcinomas promote cancer invasion by expressing MMP2 and CXCL12. Histopathology 2015 May;66(6):781-790.

51. Jensen DH, Reibel J, Mackenzie IC, Dabelsteen E. Single cell migration in oral squamous cell carcinoma - possible evidence of epithelial-mesenchymal transition in vivo. J Oral Pathol Med 2015 Oct;44(9):674-679. 